\title{
Eight Mondays: a parliamentary group ends the silence on population
}

\section{Martha Campbell}

\section{Background}

In the summer of 2006, the All Party Parliamentary Group (APPG) on Population, Development and Reproductive Health held a series of Monday hearings at Westminster, London, UK, on population growth and the Millennium Development Goals (MDGs). For a joyous moment, good science and sound politics came together.

Thirty to forty years ago, population had the salience on the international agenda that global warming now receives. In 1967, British economist and Nobel laureate James Meade drew attention to the extra investment required to build additional infrastructure and create new jobs in a country with a rapidly growing population. ${ }^{1}$ In the late 1980s, however, the subject of population growth began to be pushed off the policy agenda and largely disappeared from public discussion. The press began to treat population with a mixture of scepticism and silence, and most articles and books written about poverty or the environment did not even mention the population factor. Dr Chris Rapley, Director of the British Antarctic Survey, frequently points out that demographers are notable by their absence at scientific meetings on climate change.

\section{APPG report on population growth}

The APPG's report, published in January 2007 and entitled Return of the Population Growth Factor: Its Impact Upon the Millennium Development Goals, ${ }^{2}$ changes the policy framework for Britain, and hopefully for the rest of Europe. Every fact and statement in the report is distilled from expert witnesses who spoke at the Monday hearings, and from the written evidence submitted by about 75 contributors, including the UK's Department for International Development, international organisations [e.g. United Nations Population Fund (UNFPA), World Bank, International Planned Parenthood Federation (IPPF), World Health Organization], academic institutions (London School of Hygiene and Tropical Medicine, University of Sussex) and individual experts such as Sir David King, Chief Advisor to Her Majesty's Government and Head of the Office of Science and Technology.

The report promises to be a landmark, drawing attention to the quandary of the world's poorest countries, where $90 \%$ of the world's population growth takes place. Today the Earth is home to 6.5 billion people, a number expected to grow to between 8 and 10.5 billion by 2050 . Richard Ottaway, Member of Parliament (MP) for South Croydon, who initiated the hearings, summarised the hearings, saying: "The MDGs are difficult or impossible to achieve with current levels of population growth in the least developed countries".

Perhaps the most important is the statement by the Chair of the APPG, Christine McCafferty, MP for Calder Valley, who writes: "I hope in the next decade we will find

J Fam Plann Reprod Health Care 2007; 33(2): 75-76

School of Public Health, University of California, Berkeley, CA, USA

Martha Campbell, PhD, Lecturer

Correspondence to: Dr Martha Campbell, School of Public Health, 506 Warren Hall, University of California, Berkeley, CA 94720-7360, USA. E-mail: campbell@berkeley.edu a way to speak, from a human rights perspective, both about the importance of population stabilisation and the importance of supporting the rights of the individual to reproductive freedom and reproductive choice".

\section{The perfect storm}

A section in the report called 'The Lost Decade' outlines what might be seen as a perfect storm of factors that have eclipsed population concerns in recent years. The current concern over extremely low fertility in European countries and Japan has worried many economists and received a great deal of attention in the press. In 2004, a book launched with a big splash was entitled The End of World Population Growth in the 21st Century. ${ }^{3}$ Not recognised is the reality that India has one million more births than deaths every 20 days. Western patterns of consumption are so dominant in global warming that one can easily feel it inappropriate to focus on population growth in developing countries, even though population is the multiplier of everything we do as consumers.

The spread of AIDS has taken the oxygen out of population growth concerns. Yet even Uganda, a country decimated by AIDS but maintaining an average birth rate of 6.9 children per family, will nearly quadruple its population in the next 43 years. ${ }^{4}$ Anti-abortion activists, religious leaders and conservative think-tanks have been influential in reducing attention to population growth. They tend to welcome news reports that the population explosion is over. We must keep in mind that the most extreme and powerful advocates against abortion are also against family planning.

At the time of the United Nations 1994 International Conference on Population and Development (ICPD, or Cairo), a major policy shift occurred drawing attention to women's needs around the world. The intent was excellent, as women remain marginalised in many societies. Unfortunately, the strategy - developed by collaboration among women's groups and designed to strengthen women - was to make discussion about 'population' and 'family planning' politically incorrect. The term 'reproductive health' was considered the only way to speak of these issues, but it has been hard to measure, and too diffuse for politicians to grasp. All of the family planning work prior to 1994 was denigrated and framed as insensitive 'population control'. The political tide of 1994 promoted attention to patterns of coercion in India in the 1970s and in China's non-voluntary population programme, but not to the poor women in vast multiples of these numbers, essentially coerced into repeated childbearing even when they did not want another pregnancy. Steven Sinding, Director General of IPPF, described in the hearings the taboo about population “. ... that emerged in the run-up to Cairo and at Cairo itself. I think the taboo was the result of a mythology that equated population policies with coercion".

These political voices spoke in sharp contrast to the ICPD Programme of Action (PoA), which emphatically maintained a demographic focus. Even while highlighting the needs of women in the developing world, it called the years between 1994 and 2000 part of a "critical decade" when "the world's nations by their actions or inactions will choose from among a range of alternative demographic futures". The PoA emphasised that the difference of 720 million people between the high and low global population projections to 2015 "exceeds the current population of the African continent". 5 


\section{Impact of population growth}

The hearings were designed to focus on the impact of population growth in the world's poorest countries on their chances of achieving the MDGs by 2015. The evidence points out a series of patterns going in the wrong direction.

- Between 1990 and 2001, the number of people in extreme poverty grew from 231 million people to 318 million, an increase of $38 \%$, or 88 million people. According to the UNFPA's evidence, "The rapid pace of population growth in much of Africa and some other parts of the world means, despite global efforts, we are not even succeeding in keeping the numbers living in extreme poverty stable."6

- The challenge of reducing the proportion of people who suffer from hunger is illustrated by the evidence which shows that in 1984, the year of the infamous famine, the population of Ethiopia was 42 million. $^{7}$ Today this figure has reached 75 million and by 2050 the country is projected to have a population of 145 million. ${ }^{8}$ At the present time, 8 million Ethiopians already live on permanent food aid. ${ }^{9}$

- The challenge of providing primary schooling is described as caught in a vicious cycle of mutually destructive ways, as in high population growth countries the number of school age children can double every 20 years. ${ }^{10}$ Assuming class sizes of 40 children, an extra 2 million schoolteachers per year are required just to stand still. ${ }^{11}$ The challenge grows with time: almost $30 \%$ of the world population is under 15 years. ${ }^{12}$

- Evidence reveals at least two important causes of child mortality directly related to population growth: high fertility and reduced access to safe drinking water.

- The goal of reducing maternal mortality by $75 \%$ is viewed as difficult in countries with high fertility, which is acknowledged as strongly increasing a woman's lifetime risk of dying from pregnancy-related causes. ${ }^{13}$

- Population growth was recognised as hampering control over the spread of HIV/AIDS through two main routes: increased urbanisation and the persistence of poverty. The report also shows that family planning can sometimes be more cost-effective than voluntary counselling and testing in reducing the vertical transmission of HIV. ${ }^{14}$

- The goal of ensuring environmental sustainability is discussed in the light of the lack of access to safe drinking water. The United Nations estimates that as global population grows, by 2025 two-thirds of the world's population will face moderate to high water shortages. While many environmental problems are affected dominantly by high levels of consumption, some, such as the Nile (a limited resource), are based on population growth alone. (Today the Nile is severely depleted by the time it reaches the Mediterranean, but the combined populations of Egypt, Sudan and Ethiopia, dependent on this magnificent water source, are projected nearly to double by the year 2050.)

\section{The importance of family planning}

Although the question posed for the hearings is about the impact of rapid population growth, a second theme emerged in the testimonies: the family planning needs of the 2.7 billion people (over $40 \%$ of the world's population) who live on less than US \$2 a day. ${ }^{15}$ One area where the data are unambiguous is in the documentation of a large unmet need for family planning. An estimated 201 million married women of reproductive age do not want to bear another child within the next 2 years but are not using modern methods of contraception. There is no argument over these numbers, which belie the idea that people have large families because they choose to. The report recognised that "The ability of women to control their own fertility is absolutely fundamental to women's empowerment and equality". 16

The report recommends that support for family planning be radically increased, given the loss of support over the past decade. Support for contraceptive commodity supplies is considered a top priority. Removing the many kinds of barriers to contraception is called for, particularly given the growing understanding, as revealed in the hearings, that usually people with large families did not choose to be in this situation, but they lacked realistic access to the means and information they needed to achieve a smaller family. 17

The USA, which for many years was the global leader in family planning, has forfeited that role as a result of a fundamentalist backlash against safe abortion. The British parliament has now taken the global lead. It is to be hoped that the report will be read and acted upon by other members of the European Union.

\section{Statements on funding and competing interests \\ Funding None identified.}

Competing interests None identified.

References

1 Meade J. Population explosion, standard of living and social conflict. Economic Journal 1967; 77: 233-255.

2 All Party Parliamentary Group on Population, Development and Reproductive Health Report. Return of the Population Growth Factor: Its Impact Upon the Millennium Development Goals. January 2007. http://www.appg-popdevrh.org.uk/ [Accessed 17 February 2007]

3 Wolfgang L, Sanderson WC; Scherbov S. The End of World Population Growth in the 21st Century: New Challenges for Human Capital Formation and Sustainable Development. London, UK: Earthscan, 2004.

4 Population Reference Bureau. http://www.prb.org/Articles/ 2003/UNProjectsSlowerPopulationGrowth.aspx [Accessed 17 February 2007]

5 United Nations Population Fund (UNFPA). Programme of Action Adopted at the International Conference on Population and Development, Cairo, 5-13 September 1994. New York, NY: UNFPA, 1995; paragraph 1.4

6 United Nations Population Fund (UNFPA). Written evidence to the All Party Parliamentary Group on Population, Development and Reproductive Health, 19 June 2006; 5.

7 United Nations. Demographic Yearbook, 1989. New York, NY: United Nations, 1991; 116-167.

8 Population Reference Bureau. http://www.prb.org/Articles/ 2006/EthiopiaDHS2005.aspx [Accessed 17 February 2007].

9 United Nations World Food Programme. Annual Reports 2006; 24.

10 London School of Hygiene and Tropical Medicine. Written evidence to the All Party Parliamentary Group on Population, Development and Reproductive Health, March 2006; 12.

11 Marie Stopes International. Written evidence to the All Party Parliamentary Group on Population, Development and Reproductive Health, March 2006; 4

12 Population Reference Bureau. World Population Data Sheet 2005. www.prb.org

13 United Kingdom Department for International Development. Written evidence to the All Party Parliamentary Group on Population, Development and Reproductive Health, March 2006; 18.

14 Reynolds HW, Janowitz B, Homan R, Johnson L. The value of contraception to prevent perinatal HIV transmission. Sex Transm Dis 2006; 33: 350-356.

15 Millennium Project. http://www.unmillenniumproject.org/ documents/UNMP-FastFacts-E.pdf [Accessed 17 February 2007].

16 United Kingdom Department for International Development. Written evidence to the All Party Parliamentary Group on Population, Development and Reproductive Health, March 2006; 16. World Health Organization. Written evidence to the All Party Parliamentary Group on Population, Development and Reproductive Health, March 2006; 9.

17 Campbell M, Salin-Hodoglugil N, Potts M. Barriers to fertility regulation: a review of the literature. Stud Family Plann 2006; 637: 87-98. 